\title{
INDIKATOR PERANCANGAN OCEANARIUM TANGGAP PANDEMI
}

\author{
Sidi Ahyar Wiraguna ${ }^{1}$, Fermanto Lianto ${ }^{2}$ \\ ${ }^{1}$ Jurusan Arsitektur dan Perencanaan, Universitas Tarumanagara Jakarta \\ Email:w.wiraguna24@gmail.com \\ ${ }^{2}$ Jurusan Arsitektur dan Perencanaan, Universitas Tarumanagara Jakarta \\ Email:fermantol@ft.untar.ac.id
}

Masuk: 22-08-2021, revisi: 06-10-2021, diterima untuk diterbitkan: 27-10-2021

\begin{abstract}
ABSTRAK
Virus COVID-19 telah menyebar ke seluruh negara dan wilayah dunia, menginfeksi dan membunuh orang secara global sejak muncul pertama kali di kota Wuhan, China, akhir tahun 2019, menurut data yang dikumpulkan oleh Universitas Johns Hopkins. Dampak COVID-19 menyebabkan sejumlah Destinasi Pariwisata di Jakarta ditutup. Salah satu fasilitas umum yang terdampak adalah tempat tempat rekreasi oceanarium yang berfungsi sebagai pusat hiburan umum, pendidikan dan penelitian ilmiah. Tujuan penelitian ini adalah untuk mendapatkan indikatorindikator desain oceanarium tanggap pandemi sehingga dapat mengurangi resiko penyebaran dan penularan virus COVID-19. Penelitian ini dilakukan dengan metode kombinasi studi pustaka, wawancara, kuesioner dan observasi langsung terhadap bangunan sejenis yang sudah ada yaitu, Seaworld Ancol, Jakarta Aquarium dan Dunia Air Tawar. Beberapa teori acuan yang digunakan yang relevan dengan tema penelitian ini diantaranya adalah, teori penyebaran dan penularan virus COVID-19 melalui udara dan sistem HVAC, teori tentang oceanarium dan teori pendukung terkait lainya. Berdasarkan hasil analisis dan pembahasan diperoleh kesimpulan beberapa indikator perancangan yang dapat digunakan sebagai landasan konsep strategi desain yaitu: 1) Pentingnya ventilasi udara alami; 2) Sistem HVAC yang digunakan; 3) Membatasi durasi kunjungan di dalam ruangan tertutup; 3) Desain masa bangunan yang dipisah-pisah; 4) Meminimalisir kontak langsung antara pengunjung dengan pengelola dan pengunjung dengan pengunjung; 5) Menjaga jarak antara sesama pengunjung, pengunjung dengan operator.
\end{abstract}

Kata Kunci: HVAC; Indikator Desain; Oceanarium; Tanggap Pandemi; Jakarta.

\begin{abstract}
According to data compiled by Johns Hopkins University, the COVID-19 virus has spread to all countries and regions of the world, infecting and killing people globally since it first emerged in the Chinese city of Wuhan late last year. The impact of COVID-19 has caused several tourism destinations in Jakarta to be closed. One of the public facilities affected is an oceanarium recreation area which functions as a centre for public entertainment, education and scientific research. The purpose of this study was to obtain design indicators for a pandemic-responsive oceanarium to reduce the risk of spreading and transmitting the COVID-19 virus. This research was conducted using literature studies, interviews, questionnaires and direct observation of similar existing buildings, namely Seaworld Ancol, Jakarta Aquarium and Dunia Fresh Air. The reference theories used that are relevant to the theme of this research include the theory of the spread and transmission of the COVID-19 virus through the air and the HVAC system, the theory of the oceanarium, and other supporting theories. Based on the results of the analysis and discussion, it is concluded that several design indicators can be used as the basis for the concept of a design strategy, namely: 1) The importance of natural air ventilation; 2) HVAC system used; 3) Limiting the duration of visits in a closed room; 3) Design of a separate building mass; 4) Minimizing direct contact between visitors and managers and visitors with visitors; 5) Maintain distance between visitors, visitors and operators.
\end{abstract}

Keywords: HVAC; Design Indicators; Oceanarium; Pandemic Response; Jakarta. 


\section{PENDAHULUAN}

Corona (CO), Virus (VI), Disease (D, penyakit) yang ditemukan pada 2019 (COVID-19) telah menyebar ke 185 negara dan wilayah, menginfeksi lebih dari 2,7 juta orang dan membunuh lebih dari 190.000 orang secara global sejak muncul pertama kali di kota Wuhan, China, akhir tahun lalu, menurut data yang dikumpulkan oleh Universitas Johns Hopkins (Ratu, 2020). Pandemi yang muncul pada akhir Desember di Wuhan, Cina, telah menyebar ke seluruh dunia pada tingkat yang mengkhawatirkan - sudah 33 juta lebih kasus di seluruh dunia hingga akhir september 2020 (WHO, 2020)

Dampak COVID-19 di sejumlah Destinasi Pariwisata di Jakarta Ditutup (Halakrispen, 2020). "Mengingat penyebaran COVID-19 yang semakin mengkhawatirkan, Pemprov DKI Jakarta akan melakukan penutupan sementara kegiatan operasional usaha hiburan dan rekreasi selama dua pekan." Penutupan tersebut akan berlangsung sejak Senin, 23 Maret 2020 sampai dengan Minggu, 5 April 2020. Menindaklanjuti instruksi Gubernur DKI Jakarta Nomor 16 tahun 2020 tentang Peningkatan Kewaspadaan terhadap Risiko Penularan Infeksi Coronavirus Disease (COVID-19) di DKI Jakarta. "Mengimbau kepada penyelenggara kegiatan "Meeting, Incentive, Convention, and Exhibition" (MICE), ballroom hotel, dan balai pertemuan, untuk menunda penyelenggaraan event dan atau kegiatan sampai batas waktu yang ditentukan."

Salah satu fasilitas umum yang terdampak adalah tempat-tempat rekreasi oceanarium yang berfungsi sebagai pusat hiburan umum, pendidikan dan penelitian ilmiah. Pada umumnya bagunan oceanarium merupakan satu unit bangunan besar yang tertutup tanpa ventilasi menggunakan sirkulasi tata udara buatan HVAC (Heating Ventilation and Air Conditioning) dengan closed system circulation. Jakarta memiliki 3 wahana aquarium/oceanarium, namun yang paling banyak memiliki tingkat kunjungan adalah oceanarium yang berada di kawasan Taman Impian Jaya Ancol (Winarto, 2020). Dalam masa pandemi saat ini ketiga wahana aquarium/oceanarium sepi pengunjung.

Tujuan penelitian ini adalah mengembangkan dan menghasilkan kriteria desain arsitektur oceanarium yang mampu beradaptasi terhadap pandemi.

\section{METODE PENELITIAN}

Penelitian ini dilakukan dengan metode kombinasi antara studi pustaka, kuesioner, wawancara dan observasi langsung terhadap bangunan sejenis yang sudah ada yaitu, Seaworld Ancol, Jakarta Aquarium dan Dunia Air Tawar. Observasi langsung dilakukan oleh peneliti untuk mengetahui kondisi fisik bangunan dan masalah apa saja yang terjadi terkait dengan permasalahan pandemi. Kuesioner dilakukan dengan cara menyebarkan google form kepada pengelola tempat rekreasi/operator dengan jumlah responden masing masing 5 orang dan masyarakat umum dengan jumlah responden 48 orang. Sedangkan wawancara melalui audio video conference dilakukan kepada 2 orang ahli dibidang oceanarium sesuai dengan kebutuhan.

Dari hasil observasi, studi pustaka, kuesioner dan wawancara peneliti melakukan analisis dan review terhadap data-data, informasi dan kondisi lapangan yang diperoleh. Analisis ini dilakukan secara deskriptif dan komparatif untuk mengetahui hubungan antara beberapa faktor pandemi yang dapat mempengaruhi secara langsung dan terhadap program arsitektur oceanarium. 


\section{KAJIAN TEORI}

Oceanarium adalah akuarium laut yang berukuran besar (Rahmah \& Aqli, 2020). Pandemi adalah epidemi yang terjadi pada skala yang melintasi batas internasional, biasanya mempengaruhi sejumlah besar orang. Suatu penyakit atau kondisi bukanlah pandemi hanya karena tersebar luas atau membunuh banyak orang, tapi penyakit atau kondisi tersebut juga harus menular. Pandemi merupakan Epidemi atau wabah yang tiba-tiba menjadi sangat luas dan mempengaruhi seluruh wilayah atau dunia karena populasi yang rentan, sehingga menyebabkan tingkat kematian yang tinggi (Shiel Jr, 2018).

Virus COVID-19 menyebar terutama melalui tetesan air liur atau cairan dari hidung saat seseorang yang terinfeksi kemudian batuk atau bersin, jadi saat seseorang batuk atau bersin sebaiknya mempraktekkan etika pernapasan (misalnya, pada saat batuk sebaiknya menunduk ke arah siku yang tertekuk untuk menjaga agar cairan dari hidung atau mulut tidak menyebar). Kebanyakan orang yang terinfeksi virus COVID-19 akan mengalami penyakit pernapasan ringan hingga sedang dan sembuh. Orang tua, dan mereka yang memiliki masalah medis seperti penyakit kardiovaskular, diabetes, penyakit pernapasan kronis, dan kanker lebih berpotensi terserang dan menjadi fatal (WHO, 2020).

Virus COVID-19 dapat bekembang, menyebar, menular pada kondisi ruangan tertutup tanpa ventilasi udara, tanpa sinar matahari dan udara yang lembab (Leslie, Horve, Coil, Fretz, Eisen, \& Wymelenberga). Penyebaran dan penularan Virus COVID-19 dapat terjadi melalui sistem HVAC pada bangunan gedung tertutup dan tidak memiliki sistem ventilasi (Francesco, 2020). Laporan terbaru lainnya dari China mengklaim bahwa COVID-19 disebarkan melalui sistem HVAC di sebuah restoran ( $\mathrm{Lu}, \mathrm{Gu}, \mathrm{Li}, \& \mathrm{Xu}, 2020)$. Filter mekanis dalam sistem HVAC memiliki serat penyaring untuk memfilter partikel berukuran diatas 0,3 mikron. Beberapa filter mekanis memiliki peringkat kualitas yang berbeda, berdasarkan persentase partikel yang dihilangkan, dengan peringkat tertinggi yang biasanya digunakan pada aplikasi ruang medis, ruang operasi atau ruang steril. Gambar 1 dibawah menunjukkan tingkatan kualitas kemampuan filter (Balgeman, Meigs, Mohr, Niemöller, \& Spranzi, 2020).

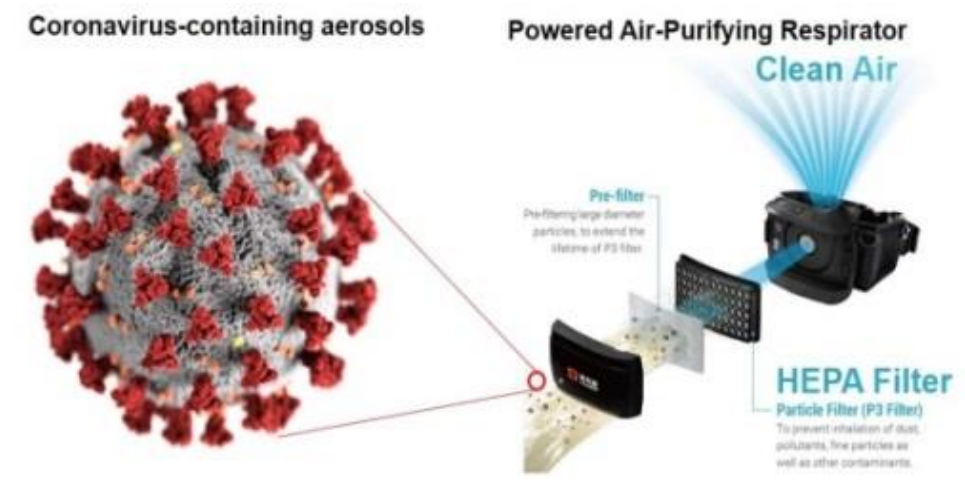

Gambar 1. Tingkatan Efisiensi Filter Udara Sistem HVAC

Sumber: https://www.imperial.ac.uk/song-group/respirators-for-covid19/, diunduh 20 Januari 2021 (Song \& Shah, 2020)

Filter Udara High-Efficiency Particulate Air (HEPA) adalah yang paling efektif dalam menghilangkan partikel berukuran dibawah 0,3 mikron. Sesuai dengan kualifikasi sistem peringkat standar Amerika Serikat (AS), filter HEPA mampu menghilangkan 99,97 persen partikel 0,3 mikron. Sedangkan Minimum Efficiency Reporting Value (MERV 12) memiliki kemampuan untuk menyaring partikel yang lebih besar mulai dari ukuran 0,3 hingga 10,0 mikron. Sistem AC di perumahan, bangunan komersial umumnya menggunakan filter dengan 
peringkat MERV 12 atau lebih rendah. Hanya beberapa sistem AC yang dapat menggunakan filter High-Efficiency Particulate Air (HEPA) (Balgeman, Meigs, Mohr, Niemöller, \& Spranzi, 2020).

\section{HASIL DAN PEMBAHASAN STUDI KASUS}

\subsection{Seaworld Ancol}

Kunjungan pada masa pandemi menurun drastis 30\%-50\%. Hal ini disebabkan masyarakat khawatir terpapar virus COVID-19 ketika berkunjung. Massa bangunan terdiri dari satu unit bangunan besar tertutup tanpa ventilasi yang cukup. Hal ini mengakibatkan tidak ada pertukaran udara baru (fresh air), kondisi seperti memungkinkan jika ada orang yang sudah tertular maka virus dapat bertahan dalam ruangan sehingga akan menular kepada pengunjung. Semua objek pamer dan fasilitas pendukung seperti food court, souvenir shop, toilet, dan tiket berada dalam satu gedung yang sama (Gambar 2).

Hal ini mengakibatkan durasi kunjungan menjadi lama (2,5-3,5 jam). Durasi kunjungan dikhawatirkan berpotensi sebagai sebagai media penularan jika udara tercemar virus COVID-19. Ventilasi udara pada bangunan utama $\pm 95 \%$ tertutup. Udara luar hanya sesekali masuk melalui pintu main entrance dan pintu keluar Ketika ada pengunjung yang masuk dan keluar gedung. Dengan sistem HVAC close system circulation beresiko menjadi tempat penyebaran dan penularan virus COVID-19. Kapasitas pengunjung dibatasi hingga 50\% dari kapasitas normal. Karena kekhawatiran akan resiko terpapar virus COVID-19. Penjualan tiket secara langsung masih dilaksanakan, masih terjadi kontak langsung antara pengunjung yang membeli tiket dengan penjual tiket.

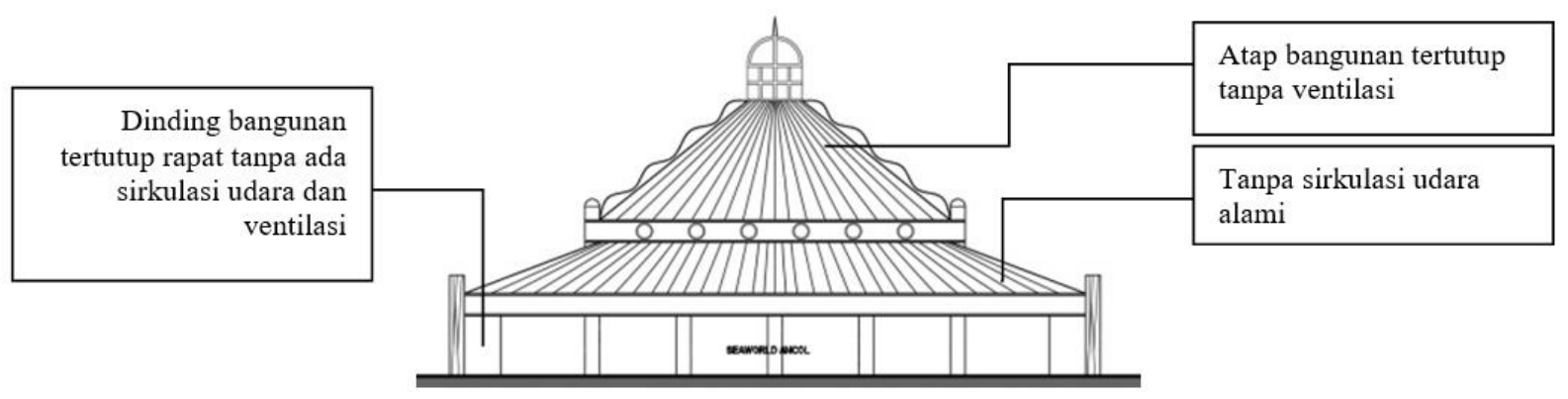

Gambar 2. Tampak Bangunan Seaworld Ancol

Sumber: Penulis, 2020

\subsection{Jakarta Aquarium}

Kunjungan pada masa pandemi menurun drastis hingga 50\%. Hal ini disebabkan masyarakat khawatir akan terpapar virus COVID-19 ketika berkunjung. Terletak pada lantai Basement mal Neo Soho (Gambar 3) di lantai Lower Ground (LG) dan Lower Ground Mezzanine (LGM), merupakan lokasi “Given”. Tanpa ventilasi udara alami, 100\% menggunakan tata udara buatan HVAC sistem central dengan close system circulation. Durasi kunjungan diperkirakan antara 2,5-3 jam. Waktu yang cukup lama dan beresiko tertular virus COVID-19. Sistem pencahayaan pada semua area wahana $100 \%$ menggunakan pencahayaan buatan (lampu). Termasuk pencahayaan pada semua area Back of House (BOH). Belum ada perubahan arsitektur yang dilakukan selama masa pandemi, kecuali melaksanakan aturan yang dianjurkan oleh pemerintah. Kapasitas pengunjung dibatasi, hingga 50\% dari kapasitas normal agar tidak terjadi kerumunan. Pada kenyataannya Physical distancing sulit terlaksana walaupun sudah dibuatkan signage di lantai, agar pengunjung selalu jaga jarak. Penjualan tiket secara langsung masih dilaksanakan, masih terjadi kontak langsung antara pengunjung yang membeli tiket dengan penjual tiket. 


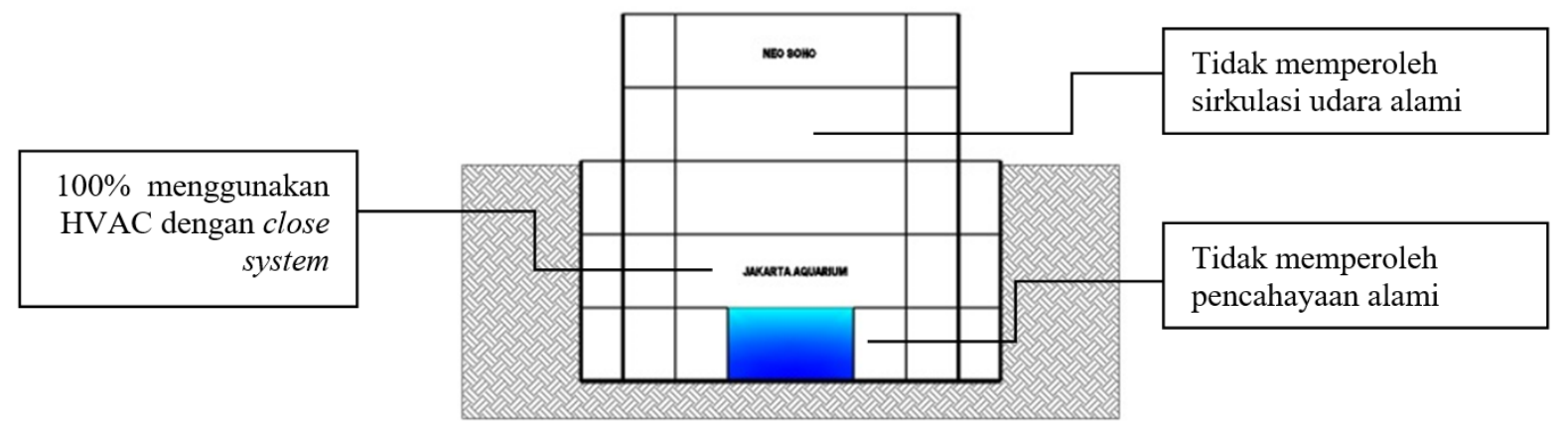

Gambar 3. Potongan Prinsip Jakarta Aquarium

Sumber: Penulis, 2020

\subsection{Dunia Air Tawar}

Terdiri dari satu unit massa bangunan. Semua objek primer dan aktivitas kunjungan berada dalam satu gedung (Indoor display). Durasi kunjungan diperkirakan antara $2 \mathrm{~s} / \mathrm{d} 2,5 \mathrm{jam}$. Waktu yang cukup lama dan beresiko terpapar virus COVID-19. Sistem AC terpasang adalah split duct dengan filter standar. Re-sirkulasi tidak dapat memfilter virus. Ventilasi udara tertutup, tidak mengoptimalkan ventilasi udara alami, sementara kondisi lapangan memungkinkan untuk melakukan hal tersebut. Sistem pencahayaan siang hari $85 \%$ adalah pencahayaan buatan (lampu). Hanya bagian tertentu yang menggunakan pencahayaan dan ventilasi alami. Penjualan tiket secara langsung masih dilakukan dan terjadi kontak langsung antara pengunjung dengan penjual tiket, berpotensi terjadi penularan. Pengelola belum mengetahui bahwa penyebaran dan penularan virus COVID-19 dapat terjadi melalui udara maupun sistem HVAC (closed system circulation).

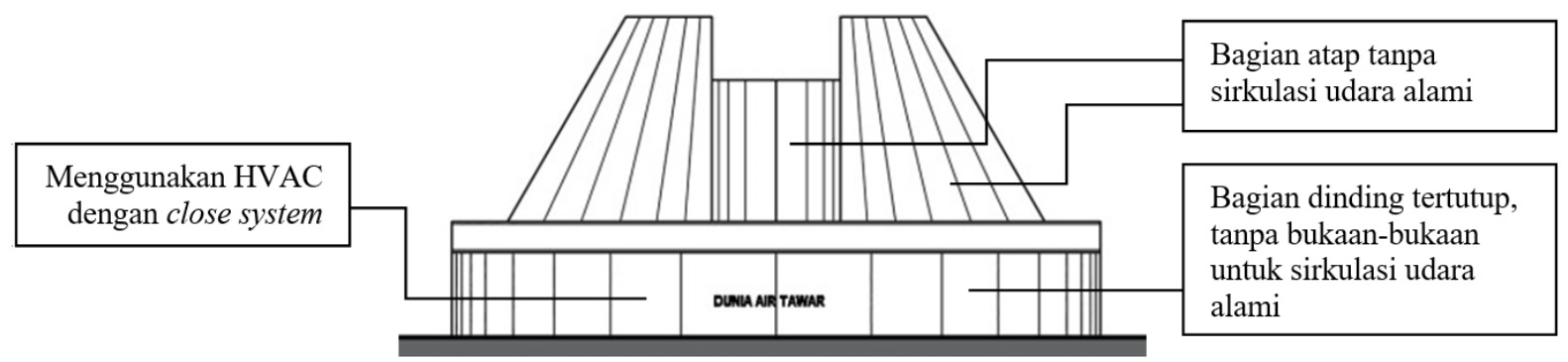

Gambar 4. Tampak Bangunan Dunia Air Tawar Sumber: Penulis, 2020

\subsection{Pencegahan Penyebaran Virus COVID-19}

Keberadaan virus belum dapat terdeteksi dengan panca indra manusia ataupun peralatan sehingga sulit mengetahui apakah pada bagian tertentu dari suatu ruangan terdapat virus COVID-19 atau tidak. Keberadaan sumber penularan atau orang yang terinfeksi tidak dapat diketahui secara pasti, walaupun prosedur pengecekan suhu tubuh sudah dilaksanakan. Orang yang bersin atau batuk tetap dapat menyebarkan virus walaupun sudah mengenakan masker. Virus COVID-19 dapat bekembang, menyebar, menular pada kondisi ruangan tertutup tanpa ventilasi udara, tanpa sinar matahari dan udara yang lembab. Sistem HVAC terpasang adalah sistem AC central, sehingga terjadi re-sirkulasi udara secara terus menerus selama operasional. Filter AC terpasang adalah filter standar, yang tidak mampu menahan/memfilter udara yang tercemar oleh virus. Tidak adanya ventilasi yang cukup untuk dapat mengganti udara yang tercemar dengan udara segar. Virus dapat menempel dan berkembang biak pada semua permukaan benda selama 3 jam hingga 7 hari. 
Dari Analisis tersebut dapat ditarik suatu jawaban untuk menyelesaikan permasalahan tersebut antara lain (Gambar 5): 1) Membuat sistem pergantian udara dalam ruangan secara berkala melalui ventilasi alami. Pergantian udara dalam ruangan dimaksud dapat dilakukan pada malam hari dan atau pada saat tidak beroperasi Ventilasi alami untuk menghindari re-sirkulasi udara yang mengandung virus secara terus menerus; 2) Memasang sistem filter AC berkualitas tinggi HEPA yang mampu memurnikan udara dalam ruangan dan menyaring virus COVID-19. Mengganti sistem AC central menjadi Multi split. Mengkombinasikan sistem tata udara buatan dan ventilasi alam; 3) Memilih material dengan kriteria yang tidak halus untuk mengantisipasi virus tidak menempel dan berkembang biak.

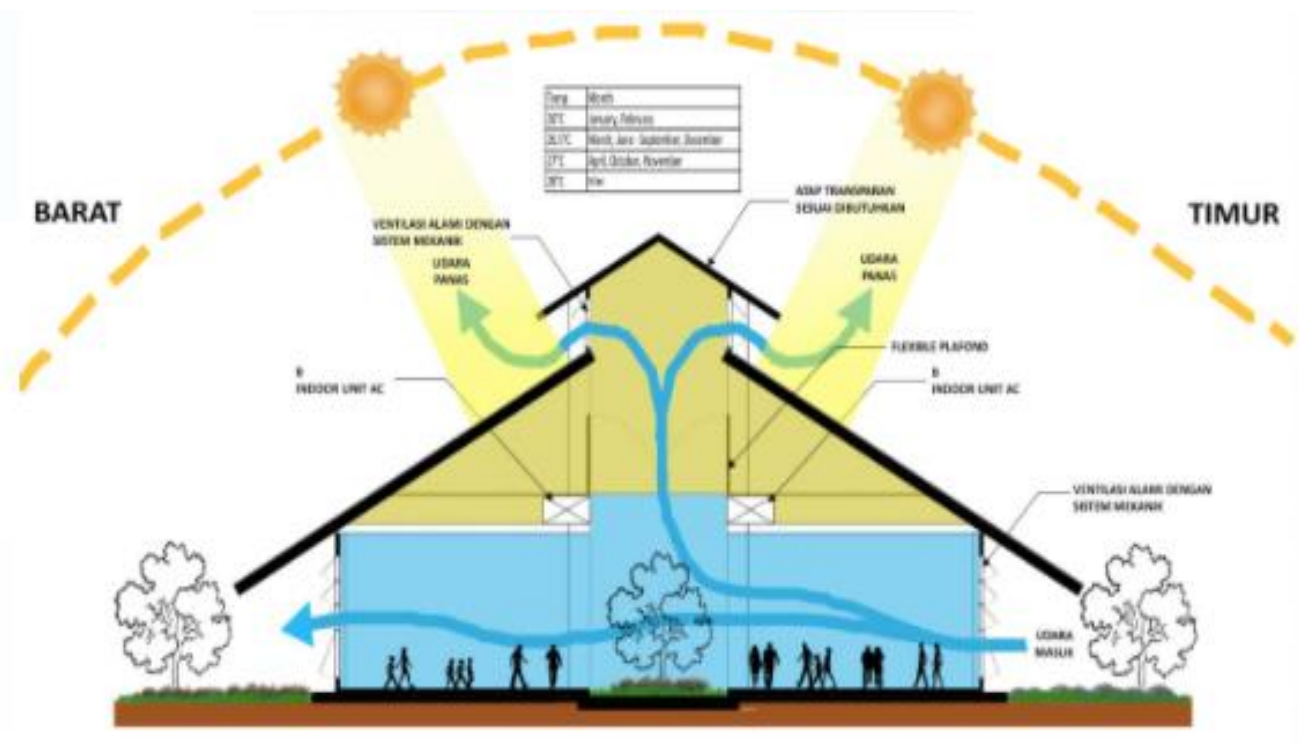

Gambar 5. Kombinasi Sistem Tata Udara Buatan dan Ventilasi Alam

Sumber: Penulis, 2020

\subsection{Indikator Desain Oceanarium}

Berdasarkan hasil analisis diperoleh beberapa indikator perancangan yang dapat digunakan sebagai landasan konsep strategi desain. Indikator-indikator tersebut meliputi ventilasi udara alami, sistem HVAC, durasi kunjungan di dalam ruangan tertutup, massa bangunan, vegetasi penataan ruang luar dan kenyamanan termal.

Secara terperinci indikator-indikator dimaksud yang sekaligus merupakan kriteria perancangan oceanarium adalah sebagai berikut: 1) Secara umum desain oceanarium yang tanggap terhadap pandemi adalah desain yang dapat mengurangi kontak langsung antara pihak operator/pengelola dengan pengunjung; 2) Setiap kelompok aktivitas dipisahkan dalam bangunan terpisah, sehingga dapat mengurangi durasi kunjungan dalam satu bagunan yang sama (Gambar 6); 3) Diperlukan Sistem Ventilasi alami atau kombinasi antara ventilasi alami dan buatan; 4) Diperlukan sistem HVAC yang mampu memfilter virus COVID-19 seperti system HVAC HEPA; 5) Pola sirkulasi pergerakan pengunjung harus dibuat satu arah dan memiliki orientasi yang jelas, sehingga selama dalam menjelajahi ruang pamer pengunjung terhindar dari kontak langsung antar sesama pengunjung, Menjaga jarak antara sesama pengunjung, pengunjung dengan operator. 


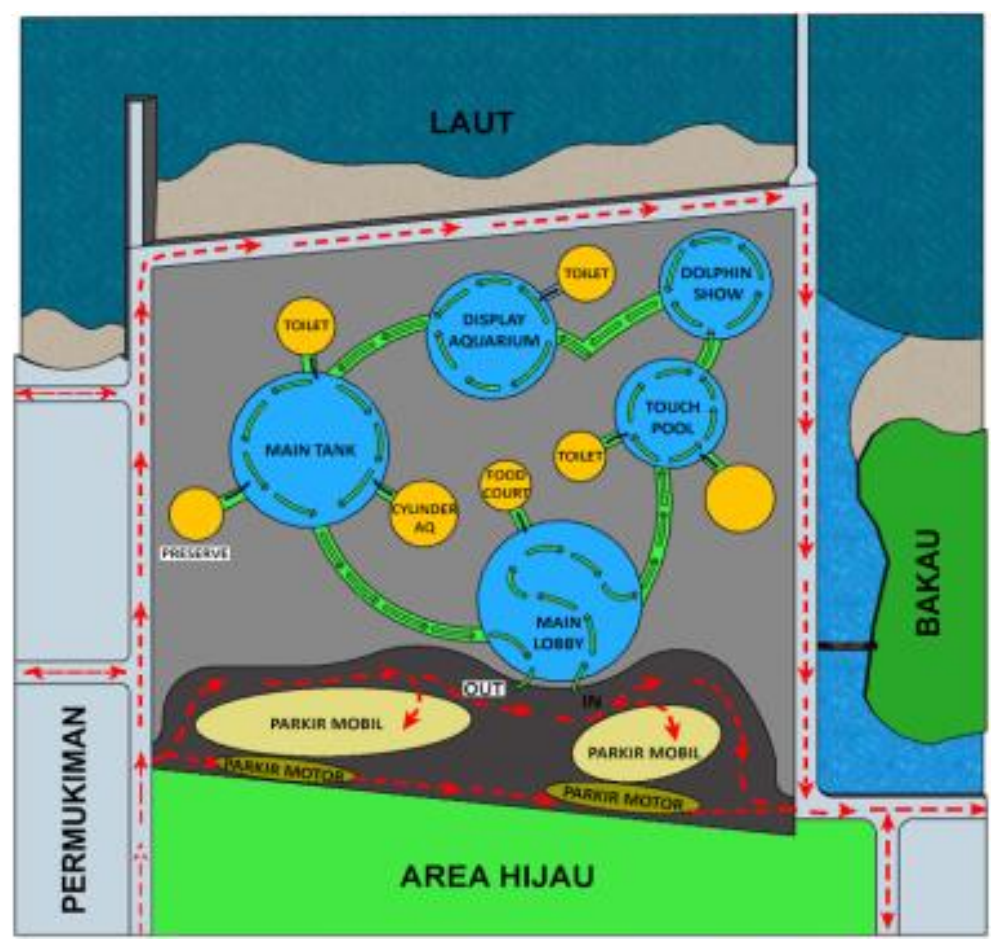

Gambar 6. Memisahkan Beberapa Kegiatan dengan Masa Bangunan yang Tepisah dan Mengatur Sirkulasi Satu Arah

Sumber: Penulis, 2020

\section{KESIMPULAN}

Secara umum desain oceanarium yang tanggap terhadap pandemi adalah desain yang dapat mengurangi kontak langsung antara pihak operator/pengelola dengan pengunjung dan pengunjung dengan pengunjung.

Desain oceanarium yang tanggap terhadap pandemi harus memiliki sistem ventilasi yang baik dan seimbang sehingga udara di dalam ruangan dapat digantikan dengan udara segar/udara baru secara periodik sesuai dengan kebutuhan operasional. Dengan menerapkan sistem kombinasi tata udara buatan (AC) dengan ventilasi alami merupakan upaya mengurangi resiko penyebaran dan penularan virus COVID-19 khususnya di dalam ruangan oceanarium. Penggunaan sistem HVAC yang dilengkapi dengan filter HEPA bisa memfilter virus COVID-19 sehingga dapat mengurangi resiko penyebaran dan penularan virus COVID-19.

Dengan membagi-bagi kelompok display dan fasilitas pendukung menjadi beberapa bagian sesuai dengan fungsi dan aktivitasnya serta diikuti dengan membuatnya menjadi beberapa massa bangunan dapat mengurangi durasi kunjungan pada satu ruangan yang sama. Hal ini merupakan strategi desain dalam rangka mengurangi resiko terpaparnya COVID-19.

Dengan menerapkan konsep bangunan tanggap iklim lingkungan setempat untuk bangunan oceanarium adalah alternatif pilihan agar mampu menghambat penyebaran dan penularan virus COVID-19. Dengan mengimplementasikan sirkulasi satu arah dengan orientasi yang jelas dapat membuat flow aliran pengunjung menjadi tertib, sehingga terhindar dari sirkulasi silang yang memungkinkan kontak langsung antar pengunjung, menjaga jarak antara sesama pengunjung, pengunjung dengan operator. 


\section{UCAPAN TERIMA KASIH}

Terima kasih kepada LPPM-UNTAR (Lembaga Penelitian dan Pengabdian kepada Masyarakat Universitas Tarumanagara) yang telah mendanai penelitian ini.

\section{REFERENSI}

Balgeman, S., Meigs, B., Mohr, S., Niemöller, A., \& Spranzi, P. (2020, July 9). McKinsey \& Company. Retrieved November 22, 2020, from www.mckinsey.com: https://www.mckinsey.com/industries/advanced-electronics/our-insights/can-hvacsystems-help-prevent-transmission-of-COVID-19

Francesco, C. (2020, August 20). Can Air-Conditioning Systems Contribute to the Spread of SARS/MERS/COVID-19 Infection?. International Journal of Environmental Research and Public Health., 17(Can Air-Conditioning Systems Contribute to the Spread of SARS/MERS/COVID-19 Infection). Retrieved september 28, 2020, from https://www.mdpi.com/journal/ijerph

Halakrispen, S. (2020, Maret 21). Medcom.id 3. Retrieved from https://www.medcom.id: https://www.medcom.id/rona/kesehatan/Rb10OjlN-dampak-COVID-19-sejumlahdestinasi-pariwisata-di-jakarta-ditutup

Leslie, Horve, P. F., Coil, D. A., Fretz, M., Eisen, J. A., \& Wymelenberga, K. V. (n.d.). 2019 Novel Coronavirus (COVID-19) Pandemic: Built Environment Considerations To Reduce Transmission. (J. Gilbert, Ed.) US National Library of Medicine, V(4). doi: 10.1128/mSystems.00245-20

Lu, J., Gu, J., Li , K., \& Xu , C. (2020, July). COVID-19 Outbreak Associated with Air Conditioning in Restaurant, Guangzhou, China, 2020. Centers for Disease Control and Prevention, VII, 1-12. doi:10.3201/eid2607.200764

Rahmah, A. A., \& Aqli, W. (2020). Konsep Arsitektur Biomimetik pada Bangunan Oseanarium. ARTEKS: Jurnal Teknik Arsitektur, 5(2), 297-306. doi:https://doi.org/10.30822/arteks.v5i2.442

Ratu, R. (2020, April 26). COVID-19 Bikin Ekonomi Dunia Babak Belur, Ini 7 Buktinya! Jakarta: CNBC Indonesia. $\quad$ Retrieved from https://www.cnbcindonesia.com/news/20200425223807-4-154461/COVID-19-bikinekonomi-dunia-babak-belur-ini-7-buktinya.

Shiel Jr, W. (2018, 12 12). MedicineNet. Retrieved from https://www.medicinenet.com: https://www.medicinenet.com/pandemic/definition.htm

Song, Q., \& Shah, N. (2020, Maret 30). https://www.imperial.ac.uk/song-group/respirators-forcovid19/. (Imperial College London) Retrieved august 2, 2021, from https://www.imperial.ac.uk/song-group/respirators-for-covid19/

WHO. (2020, January 5). world health organization. Retrieved September 24, 2020, from www.who.int: https://www.who.int/csr/don/05-january-2020-pneumonia-of-unkowncause-china/en/

Winarto, Y. (2020, Oktober 05). Pembangunan Jaya Ancol (PJAA) mengejar target kunjungan lampaui angka 20 juta. (Y. Winarto, Editor, \& Kontan.co.id) Retrieved September 12, 2020, from Kontan: https://industri.kontan.co.id/news/pembangunan-jaya-ancol-pjaamengejar-target-kunjungan-lampaui-angka-20-juta 